\title{
The Designer Antimicrobial Peptide A-hBD-2 Facilitates Skin Wound Healing by Stimulating Keratinocyte Migration and Proliferation
}

\author{
Bobin Miab Jing Liu ${ }^{a}$ Yi Liu ${ }^{a}$ Liangcong Hua Yukun Liub,c Adriana C. Panayi ${ }^{\mathrm{b}}$ \\ Wu Zhou a Guohui Liua \\ aDepartment of Orthopaedics, Union Hospital, Tongji Medical College, Huazhong University of Science \\ and Technology, Wuhan, China, 'Division of Plastic Surgery, Brigham and Women's Hospital, Harvard \\ Medical School, Boston, USA, 'Department of Plastic Surgery, Union Hospital, Tongji Medical College, \\ Huazhong University of Science and Technology, Wuhan, China
}

\section{Key Words}

Antimicrobial peptide $\cdot$ Keratinocytes $-\mathrm{HBD}-2 \cdot \mathrm{A}-\mathrm{hBD}-2 \cdot$ Cytotoxicity

\begin{abstract}
Background/Aims: Antimicrobial peptides are effective promoters of wound healing but are susceptible to degradation. In this study, we replaced the GIGDP unit on the N-terminal of the endogenous human antimicrobial peptide hBD-2 with APKAM to produce A-hBD-2 and analyzed the effect on wound healing both in vitro and in vivo. Methods: The effects of A-hBD-2 and hBD-2 on cytotoxicity and proliferation in keratinocytes were assessed by Cell Counting Kit- 8 assay. The structural stability and antimicrobial activity of hBD-2 and A-hBD-2 were evaluated against Staphylococcus aureus. RNA and proteins levels were evaluated by real-time PCR and western blotting, respectively. Cell migration was evaluated using a transwell assay. Cell cycle analysis was performed by flow cytometry. Wound healing was assessed in SpragueDawley rats. Epidermal thickness was evaluated by hematoxylin and eosin staining. Results: We found that hBD-2 exhibited cytotoxicity at high concentrations and decreased the structural stability in the presence of high sodium chloride concentrations. A-hBD-2 exhibited increased structural stability and antimicrobial activity, and had lower cytotoxicity in keratinocytes. A-hBD-2 increased the migration and proliferation of keratinocytes via phosphorylation of EGFR and STAT3 and suppressed terminal differentiation of keratinocytes. We also found that A-hBD-2 elicited mobilization of intracellular $\mathrm{Ca}^{2+}$ and stimulated keratinocytes to produce pro- and anti-inflammatory cytokines and chemokines via phospholipase $\mathrm{C}$ activation. Furthermore, A-hBD-2 promoted wound healing in vivo. Conclusion: Our data suggest that A-hBD-2 may be a promising candidate therapy for wound healing.

B. Mi and J. Liu contributed equally to this work.




\section{Cellular Physiology Cell Physiol Biochem 2018;51:647-663 and Biochemistry \begin{tabular}{l|l} 
DOI: $10.1159 / 000495320$ & 2018 The Author(s). Published by S. Karger AG, Basel
\end{tabular}

\section{Introduction}

Skin is a complex organ with numerous functions that include its role as an antimicrobial barrier. Upon injury, keratinocyte stimulation and mesenchymal stromal cell secretion increase levels of antimicrobial peptides (AMPs) in the skin [1, 2]. AMPs are naturally abundant peptides with a broad-spectrum antimicrobial activity. In addition, AMPs also play vital roles in promoting cell migration and proliferation, chemokine and cytokine production, and wound closure $[3,4]$.

Human beta-defensins (hBDs) are a group of AMPs that help to form the protective barrier of the skin. Four kinds of hBDs-hBD-1, hBD-2, hBD-3, and hBD-4-have recently been identified and are characterized by direct antimicrobial activity and immunomodulatory functions [5]. In addition, hBDs are thought to stimulate cell migration and have both proand anti-inflammatory functions $[3,6,7]$. Importantly, hBDs participate in wound healing by promoting keratinocyte migration and proliferation in addition to endothelial cell proliferation [8]. Although the effects of hBDs on wound healing appear promising, their application is hindered by their low stability in vivo and their toxicity in mammalian cells when used at high concentrations [9].

An ideal AMP should have broad-spectrum antimicrobial activity, low cytotoxicity, and the capacity to withstand the conditions of the host environments, including high salt concentrations. Replacement of the GIGDP unit on the N-terminal of hBD-2 (GIGDPVTCLKSGAICHPVFCPRRYKQIGT CGLPGTKCCKKP) as APKAM (A, alanine; $\mathrm{P}$, proline; $\mathrm{K}$, lysine; $\mathrm{M}$, methionine) improves the structural stability and antimicrobial activity of hBD-2 under physiological conditions. This is termed A-hBD-2 (APKAMVTCLKSGAICHPVFCPRRYKQIGTCGLPGTKCCKKP). The protein sequence of A-hBD-2 was compared with that of hBD-2 using the online tool ProtParam (http://web.expasy.org/ protparam/), revealing that the total number of positively charged residues increased and the grand average of hydropathy decreased. Previous studies have reported that a higher number of positively charged residues and higher hydrophobicity are closely related to improved antimicrobial activity and structural stability [10, 11]. To verify that the structure of A-hBD-2 is more stable than that of hBD-2, the online tool "The PSIPRED Protein Sequence Analysis Workbench" (http://bioinf.cs.ucl. ac.uk/psipred/) was used to predict the secondary structure of hBD-2 and A-hBD-2. An amphipathic $\alpha$-helix was found in the secondary structure of A-hBD-2 (Fig. 1), which highlighted the higher structural stability and increased antimicrobial activity of A-hBD-2 [12]. Moreover, the helicity of the $\alpha$-helix improves the specificity of antimicrobial peptides [13]. In this study, we compared the cytotoxicity, structure stability, and antibacterial activity of A-hBD-2 and hBD-2. and assessed the effects of A-hBD-2 on keratinocytes and wound healing.

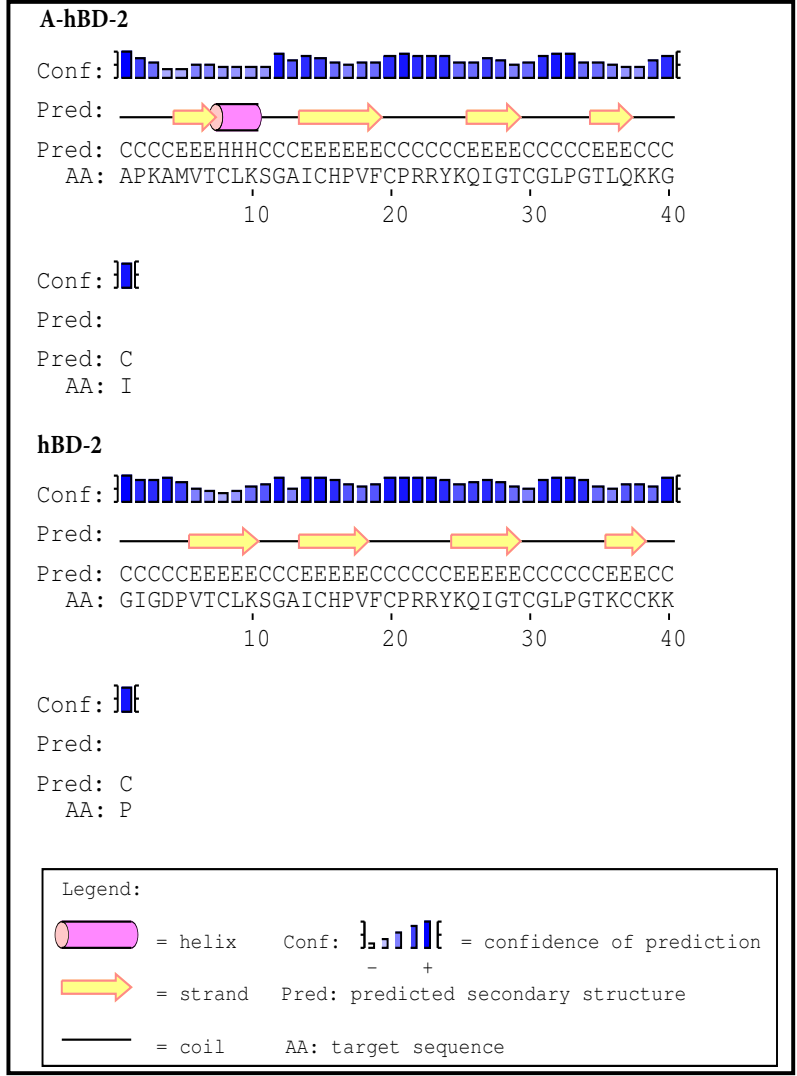

Fig. 1. Secondary structure of hBD-2 and A-hBD-2. 


\section{Cellular Physiology Cell Physiol Biochem 2018;51:647-663 and Biochemistry Published on/ne $\begin{aligned} & \text { DOI: } 10.1159 / 000495320 \\ & \text { (c) } 2018 \text { The Author(s). Published by S. Karger AG, Basel } \\ & \text { www.karger.com/cpb }\end{aligned}$ \\ Mi et al.: a-Hbd-2 Promotes Wound Healing via Keratinocyte Stimulation}

\section{Materials and Methods}

\section{Ethics statement}

All experimental procedures, including the use of cells and animal samples, were approved by the Institutional Animal Care and Use Committee at Tongji Medical College, Huazhong University of Science and Technology. All experiments were performed in accordance with the relevant guidelines and regulations of Tongji Medical College, Huazhong University of Science and Technology.

\section{Biological materials}

HaCaT cells were purchased from the Chinese Academy of Science and cultured in Dulbecco's modified Eagle's medium (DMEM) containing $10 \%$ fetal bovine serum (FBS) at $37^{\circ} \mathrm{C}$ under an atmosphere of $5 \%$ $\mathrm{CO}_{2}$. Antibodies raised against STAT 3, phosphor-STAT 3, cyclin D1, cyclin D3, KRT 1, KRT 5, KRT 10, KRT14, and glyceraldehyde-3-phpsphate-dehydrogenase (GAPDH) were purchased from Abcam (Cambridge, UK). Antibodies raised against EGFR, phosphor-EGFR were purchased from Cell Signaling Technology (Danvers, MA). AG1478 (EGFR inhibitor), S31-201 (STAT3 inhibitor), and U73122 (PLC inhibitor) were purchased from Selleckchem (Munich, Germany). Protease inhibitor cocktail was purchased from Roche (Basel, Switzerland). IL-6, IL-10, TNF- $\alpha$, and MCP-1 enzyme-linked immunosorbent assay (ELISA) kits were purchased from Bio-Swamp Life Science (Shanghai, China).

\section{Peptides and enzymes}

The synthetic peptides hBD-2 (GIGDPVTCLKSGAICHPVFCPRRYKQIGTCGLPGTKCCKKP) and A-hBD-2 (APKAMVTCLKSGAICHPVFCPRRYKQIGTCGLPGTKCCKKP) were synthesized by Mimotopes PTY Ltd. (Wuxi, China). Synthesized peptides were purified to over $95 \%$ by reversed-phase high-pressure liquid chromatography (30 $\mathrm{m} \times 25 \mu \mathrm{m}$, Beijing ChuangXinTongHeng Science and Technology Co., Ltd., Beijing, China). The peptide content of lyophilized samples was determined by quantitative amino acid analysis on a LC 3000 amino acid analyzer ( $4.6 \mathrm{~mm} \times 250 \mathrm{~mm}$, Beijing ChuangXinTongHeng Science and Technology Co., Ltd.). The analysis results for hBD-2 and A-hBD-2 can be found in Fig. S1 (For all supplemental material see www.karger.com/10.1159/000495320).

\section{Isolation and culture of human keratinocytes}

Normal skin was obtained from patients who underwent plastic surgery with appropriate approval from the Wuhan Union Hospital Committee on Human Research. Skin tissue was incubated overnight at $37^{\circ} \mathrm{C}$ in keratinocyte selection medium (epidermal keratinocyte medium CnT07, low $\mathrm{Ca}^{2+}$, CELLnTEC, Bern, Switzerland) with Dispase II (Roche). The epidermis was separated from the dermis using two pairs of forceps. The epidermis was cut into pieces and incubated in trypsin for $30 \mathrm{~min}$ at $37^{\circ} \mathrm{C}$. Freshly isolated cells were washed with medium and incubated with $\mathrm{CnT} 07$ selection medium at $37^{\circ} \mathrm{C}$ in a humidified atmosphere containing $5 \% \mathrm{CO}_{2}$. The medium was changed every $2-3$ days. Cell passages $2-3$ were used for the experiments.

\section{Cytotoxicity and proliferation assay in vitro}

To analyze the effect of hBD-2 and A-hBD-2 on cytotoxicity and proliferation, HaCaT cells were cultured in 96-well plates $\left(10^{4}\right.$ cells/well) in DMEM with $10 \%$ FBS for $24 \mathrm{~h}$. For the cytotoxicity assay, cells were incubated with various concentration of hBD-2 or A-hBD-2 for $24 \mathrm{~h}, 48 \mathrm{~h}$, or $72 \mathrm{~h}$. For the proliferation assay, cells were incubated with hBD-2, A-hBD-2, A-hBD-2 + AG1478, or A-hBD-2 + S3I-201 for 24 h, 48 h, or 72 h. Thereafter, cells were treated with Cell Counting Kit-8 (CCK8; MedChemExpress, Monmouth Junction, NJ, USA) reagent and cultured for $2 \mathrm{~h}$. Absorbance was detected at $450 \mathrm{~nm}$. For the cytotoxicity assay, data were collected and compared with certain concentrations of peptides and $0 \mu \mathrm{g} / \mathrm{mL}$ peptides. For the proliferation assay, data were collected and compared between the experimental and control groups.

\section{Salt resistance assay and antimicrobial activity assay}

The structural stability and antimicrobial activity assay of hBD-2 and A-hBD-2 were determined against Staphylococcus aureus in various concentrations of sodium chloride ( $\mathrm{NaCl}$ ) solution. Briefly, $S$. aureus was cultured at $37^{\circ} \mathrm{C}$ in lysogeny broth (LB) medium. Bacteria were sub-cultured at 1:300, grown to mid-log phase, and harvested by centrifugation at $600 \times \mathrm{g}$. After washing the pellets, approximately $1 \times$ 


\section{Cellular Physiology Cell Physiol Biochem 2018;51:647-663

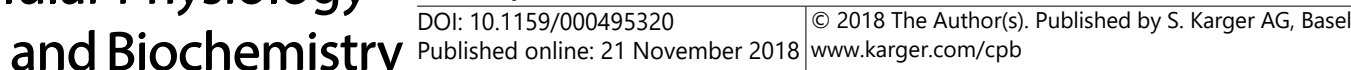 \\ Mi et al.: a-Hbd-2 Promotes Wound Healing via Keratinocyte Stimulation}

$10^{6}$ colony forming units (CFU) $/ \mathrm{mL}$ was diluted in $1 \%$ lysogeny broth-sodium phosphate buffer. Dried hBD2 and A-hBD-2 were then mixed with the above suspension and incubated for $3 \mathrm{~h}$ at $37^{\circ} \mathrm{C}$. Subsequently, $10 \mu \mathrm{L}$ of the mixture was extracted and the reaction was stopped by a 1000 -fold dilution with distilled water. Various concentrations of $\mathrm{NaCl}$ were added and aliquots were manually spread on LB agar plates. After $24 \mathrm{~h}$ at $37^{\circ} \mathrm{C}$ the colonies were counted and the percentiles of inhibition were calculated. Three single experiments were carried out.

Cell cycle assay

Cell cycle progression was detected with propidium iodide (Sigma-Aldrich, MO) staining using a flow cytometer. Briefly, cells were seeded in 6-well culture plates and treated with vehicle, $20 \mu \mathrm{g} / \mathrm{mL} \mathrm{hBD}-2,20$ $\mu \mathrm{g} / \mathrm{mL}$ A-hBD-2, $20 \mu \mathrm{g} / \mathrm{mL}$ A-hBD-2 and $50 \mathrm{~nm}$ AG1478, or $20 \mu \mathrm{g} / \mathrm{mL}$ A-hBD-2 and $50 \mu \mathrm{M}$ S3I-201. After incubation for $48 \mathrm{~h}$, cells were fixed with $70 \%$ cold ethanol at $4^{\circ} \mathrm{C}$ overnight. The cells were then rehydrated, washed twice with ice-cold phosphate-buffered saline (PBS), and incubated with $10 \mu \mathrm{L}$ RNase at $37^{\circ} \mathrm{C}$ for $30 \mathrm{~min}$. The cell cycle was analyzed by fluorescence-activated cell sorting on a flow cytometer (FACS Calibur, Becton Dickinson, San Jose, CA).

\section{Cell migration assay}

Cell migration was measured using a transwell chamber (8- $\mu$ m pore size; Costar, Corning, NY). Cells in serum-free media were placed in the upper chamber and media containing $10 \% \mathrm{FBS}$ was added to the lower chamber. Then, the vehicle, $20 \mu \mathrm{g} / \mathrm{mL}$ hBD-2, $20 \mu \mathrm{g} / \mathrm{mL} \mathrm{A-hBD-2,} 20 \mu \mathrm{g} / \mathrm{mL}$ A-hBD-2 and $50 \mathrm{~nm}$ AG1478, or $20 \mu \mathrm{g} / \mathrm{mL}$ A-hBD-2 and $50 \mu \mathrm{M} \mathrm{S3I-201}$ were added into the lower chamber. After $48 \mathrm{~h}$ incubation, the migrated cells were counted under a microscope.

\section{Western blot analysis}

HaCaT cells were treated with vehicle, $20 \mu \mathrm{g} / \mathrm{mL} \mathrm{hBD}-2,20 \mu \mathrm{g} / \mathrm{mL}$ A-hBD-2, and $20 \mu \mathrm{g} / \mathrm{mL}$ A-hBD-2 and $50 \mathrm{~nm}$ AG1478 or $20 \mu \mathrm{g} / \mathrm{mL}$ A-hBD-2 and $50 \mu \mathrm{M}$ S3I-201 for $20 \mathrm{~min}$ (EGFR, p-EGFR, STAT3, p-STAT3) or for $48 \mathrm{~h}$ (cyclin D1, cyclin D3, KRT1, KRT5, KRT10, KRT14), and total protein was extracted with RIPA lysis buffer containing $1 \%$ phenylmethanesulfonyl fluoride and $1 \%$ protease inhibitor cocktail. Equal amounts of total proteins were separated on an 8-10\% sodium dodecyl sulfate-polyacrylamide gel electrophoresis run at $80-120 \mathrm{~V}$ for $1-2 \mathrm{~h}$, and proteins on the gel were transferred onto a polyvinylidene fluoride membrane (300 $\mathrm{mA}, 60-90 \mathrm{~min}$ ). The membrane was incubated with the primary antibodies at $4^{\circ} \mathrm{C}$ overnight. The membrane was then incubated for $30 \mathrm{~min}$ with secondary antibodies at room temperature. Band visualization was conducted with an ECL Advance Western Blotting Detection Kit. Densities were calculated by the Quantity One Software (Canon, Melville, NY) and normalized by GADPH (1:10000, Abcam, \#ab37168). The following antibodies were used: cyclin D1 (1:3000, Abcam, \#ab134175), cyclin D3 (1:1000, Abcam, \#ab63535), antiphospho-EGFR (1:1000, Cell Signaling Technology, \#3777), anti-EGFR (1:1000, Cell Signaling Technology, \#4267); anti-phospho-STAT3 (1:1000, Abcam, \#ab76315); anti-STAT3 (1:3000, Abcam, \#ab119352); KRT1 (1:1000, Abcam, \#ab93652), KRT5 (1:1000, Abcam, \#ab53121), KRT10 (1:10000, Abcam, \#ab76318), KRT14 (1:20000, Abcam, \#ab51054), loricrin (1:2000, Abcam, \#ab183646).

\section{Real-time PCR}

HaCaT cells were treated with vehicle, $20 \mu \mathrm{g} / \mathrm{mL}$ hBD-2, $20 \mu \mathrm{g} / \mathrm{ml} \mathrm{A}-\mathrm{hBD}-2,20 \mu \mathrm{g} / \mathrm{mL}$ A-hBD-2 and $50 \mathrm{~nm}$ AG1478, or $20 \mu \mathrm{g} / \mathrm{mL}$ A-hBD-2 and $50 \mu \mathrm{M}$ S3I-201 for $6 \mathrm{~h}$, and total RNA was extracted using the Trizol one-step method according to the manufacturer's guidelines (Invitrogen Inc., Carlsbad CA). Reverse transcription of the RNA was performed with PrimeScript $^{T M}$ RT reagent Kit with gDNA Eraser (TaKaRa Bio Inc., Kusatsu, Japan). qRT-PCR was carried out using SYBR® Premix Ex Taq $^{T M}$ (TaKaRa Bio). The primer sequences are shown in Table 1. The reaction conditions: pre-denaturation at $95^{\circ} \mathrm{C}$ for $1 \mathrm{~min}$, denaturation at $95^{\circ} \mathrm{C}$ for $15 \mathrm{~s}$, annealing at

Table 1. Primer sequences of RTPCR. Note:qRT-PCR:quantitative realtime polymerase chain reaction; IL6:interleukin 6;TNF- $\alpha$ : tumor necrosis factor alpha;IL-10: interleukin 10;MCP1:monocyte chemoattractant protein-1; F: forward;R:reverse

\begin{tabular}{|c|c|}
\hline $\begin{array}{l}\text { Target } \\
\text { genes }\end{array}$ & Primer Sequence \\
\hline \multirow[t]{2}{*}{ IL-6 } & F: 5`-TCAGCCCTGAGAAAGGAGACAT-3` \\
\hline & R: 5`- GCTCTGGCTTGTTCCTCACTACT-3` \\
\hline \multirow[t]{2}{*}{ TNF- $\alpha$} & F: $5 `$ - GCTCTGGCTTGTTCCTCACTACT-3` \\
\hline & R: 5`- CTTGTCACTCGGGGTTCGAG-3` \\
\hline \multirow[t]{2}{*}{ IL-10 } & F: 5`- AACCTGCCTAACATGCTTCG-3` \\
\hline & R: 5`- GAGTTCACATGCGCCTTGAT-3` \\
\hline \multirow[t]{2}{*}{ MCP-1 } & F: 5`- AGAATCACCAGCAGCAAGTGTC-3` \\
\hline & R: 5`- TGTTCAAGTCTTCGGAGTTTGG-3` \\
\hline \multirow[t]{2}{*}{ Ioricrin } & F: 5`- GCTACGGAGGCGTCTCTAGC-3` \\
\hline & R: 5`- TCTGAGTGACCTGCTGCGAG-3` \\
\hline \multirow[t]{2}{*}{ GAPDH } & F: $5 `$ - CATCATCCCTGCCTCTACTGG- ${ }^{`}$ \\
\hline & R: 5`-GTGGGTGTCGCTGTTGAAGTC-3` \\
\hline
\end{tabular}




\section{Cellular Physiology Cell Physiol Biochem 2018;51:647-663

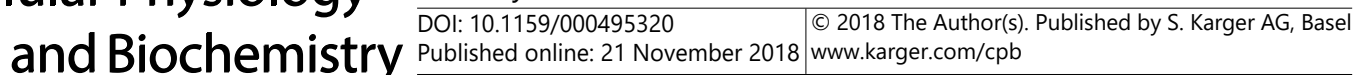

$58^{\circ} \mathrm{C}$ for $20 \mathrm{~s}$, and extension at $72^{\circ} \mathrm{C}$ for $45 \mathrm{~s}$, with a total of 40 cycles. A qRT-PCR system was used (model: StepOne ${ }^{\mathrm{TM}}$ Real-Time PCR, Thermo Fisher Scientific, Waltham, MA), with GAPDH as an internal reference for the target gene. The ratio of the relative expression of genes was calculated using the $2^{-\Delta \Delta c t}$ method. Three single experiments were carried out.

\section{ELISA}

After $\mathrm{HaCaT}$ cells were treated with vehicle, $20 \mu \mathrm{g} / \mathrm{mL}$ hBD-2, $20 \mu \mathrm{g} / \mathrm{mL}$ A-hBD-2, and $20 \mu \mathrm{g} / \mathrm{mL}$ A-hBD-2 and $50 \mathrm{~nm}$ AG1478 or $20 \mu \mathrm{g} / \mathrm{mL}$ A-hBD-2 and $50 \mu \mathrm{M} \mathrm{S3I-201}$ for $48 \mathrm{~h}$, the levels of IL-6, IL-10, TNF- $\alpha$, and MCP- 1 in the cell supernatants were measured using an ELISA kit. All analyses and calibrations were performed in duplicate. Optical densities were determined using an absorbance microplate reader at $450 \mathrm{~nm}$ (Elx808 ${ }^{\mathrm{TM}}$ Bio-TeK Instruments Inc., Winooski, VT).

\section{Measurement of intracellular $\mathrm{Ca}^{2+}$ concentration}

$\mathrm{HaCaT}$ cells were detached from culture plates using $0.25 \%$ trypsin, washed twice with PBS containing $0.2 \%$ bovine serum albumin, $0.1 \%$ glucose, and $30 \mu \mathrm{M} \mathrm{CaCl}_{2}$, and resuspended in the same buffer at a density of $2 \times 10^{6}$ cells $/ \mathrm{mL}$. After loading with $4 \mu \mathrm{M}$ Fura-2AM (Beyotime Biotechnology, Shanghai, China) for $1 \mathrm{~h}$ at $37^{\circ} \mathrm{C}$, cells were washed three times and resuspended in washing buffer. Fura-2-AM-loaded cells were stimulated with medium containing $0.01 \%$ acetic acid, $20 \mu \mathrm{g} / \mathrm{mL}$ hBD-2 or $20 \mu \mathrm{g} / \mathrm{mL}$ A-hBD-2 $(0-200 \mathrm{~s})$, and fluorescence was measured at $340 \mathrm{~nm}$ excitation and $510 \mathrm{~nm}$ emission, using an EnSpire spectrofluorometer (PerkinElmer, Inc., Waltham, MA).

\section{Animal experiments}

A total of 15 male Sprague-Dawley rats (age 4-6 weeks) were purchased from The Center of Experimental Animal, Tongji Medical College, Huazhong University of Science and Technology. The rats were anesthetized using $10 \%$ chloral hydrate $(0.3 \mathrm{~mL} / 100 \mathrm{~g}$ body weight). One full-thickness dorsal wound was created on each rat. The rats were randomly divided into three groups: control group, hBD-2 group, and A-hBD-2 group. PBS ( $1 \mathrm{~mL}$ ) and $20 \mu \mathrm{g} / \mathrm{mL}$ hBD-2 or $20 \mu \mathrm{g} / \mathrm{mL}$ A-hBD-2 were applied directly to each wound via a small dropper. The wounds were covered with transparent dressings (Tegaderm ${ }^{\mathrm{TM}}$ Film) to prevent the loss of PBS and hBD-2 or A-hBD-2. All rats were kept on a 12-h light-dark cycle with free access to food and water. The protocol was approved by the Institutional Animal Care and Use Committee at Tongji Medical College, Huazhong University of Science and Technology. After 10 days, the rats were sacrificed, and the central tissue of the wound was harvested for hematoxylin and eosin (H\&E) staining.

\section{Photography and wound area measurement}

The wound was monitored by taking digital photographs on days $0,3,5,7$, and 10 . Wound areas were calculated from the photographs with Image-Pro Plus (version 6.0, Media Cybernetics, Inc., Rockville, MD; $\mathrm{n}$ $=5 /$ group). The wound closure rate was calculated as a percentage using the following formula:

Wound closure rate $(\%)=$ (wound area on day zero - wound area on a particular day)/wound area on day zero $\times 100$

\section{H\&E staining}

Tissues were fixed overnight in 4\% (wt/vol) paraformaldehyde in PBS, embedded in paraffin, and sliced into $4-\mu \mathrm{m}$ sections. The sections were deparaffinized in three changes of xylene and rehydrated through a graded series of ethanol. The sections were stained with hematoxylin for $5 \mathrm{~min}$ and eosin for $1 \mathrm{~min}$. The H\&E-stained slides were photographed using a microscope at 200x (IX51, Olympus, Tokyo, Japan). The epidermal thickness was evaluated in three fields of each sample. Three independent observers blinded to the experiments completed these analyses and a mean value of each measurement was taken for statistical analysis.

\section{Statistical analysis}

Statistical analyses were conducted using GraphPad Prism 6.0 (GraphPad Software, Inc, La Jolla, CA). Results are presented as the mean \pm standard deviation (SD). Statistically significant differences were determined using one-way analysis of variance test or the Student's $t$ test. A value of $\mathrm{P}<0.05$ was considered statistically significant. 


\section{Cellular Physiology Cell Physiol Biochem 2018;51:647-663 and Biochemistry \begin{tabular}{l|l} 
DOI: 10.1159/000495320 & (c)18 The Author(s). Published by S. Karger AG, Basel \\
wublion
\end{tabular}

\section{Results}

\section{Cytotoxicity of A-hBD-2 on keratinocytes}

Previous studies have shown that high concentrations of hBD-2 have cytotoxic effects in cells. In this study, we assessed the cytotoxicity of hBD-2 and A-hBD-2 on HaCaT cells with CCK8. Our results showed that hBD-2 exhibited significant cytotoxic effects on HaCaT cells at concentrations of $70 \mu \mathrm{g} / \mathrm{mL}$ and $100 \mu \mathrm{g} / \mathrm{mL}$ after $24 \mathrm{~h}, 48 \mathrm{~h}$, and $72 \mathrm{~h}$ of incubation, and $50 \mu \mathrm{g} / \mathrm{mL}$ hBD-2 showed cytotoxic effects in HaCaT cell after $72 \mathrm{~h}$. However, various concentrations $(0-100 \mu \mathrm{g} / \mathrm{mL})$ of A-hBD-2 showed no cytotoxicity in HaCaT cells, although $100 \mu \mathrm{g} / \mathrm{mL}$ A-hBD-2 showed no significant difference compared with $0 \mu \mathrm{g} / \mathrm{mL} \mathrm{A-hBD}-2$ at $72 \mathrm{~h}$. In addition, $20 \mu \mathrm{g} / \mathrm{mL} \mathrm{hBD}-2$ and $30 \mu \mathrm{g} / \mathrm{mL}$ A-hBD-2 showed the lowest cytotoxic effects in HaCaT cells (Fig. 2).

\section{Antimicrobial activity and structural stability}

Our study found that at peptide concentrations of 0 and $30 \mu \mathrm{g} / \mathrm{mL} \mathrm{hBD}-2$ and A-hBD-2 had similar anti-S. aureus activity. However, A-hBD-2 had higher anti-S. aureus activity than did hBD-2 at concentrations of $50 \mu \mathrm{g} / \mathrm{mL}, 70 \mu \mathrm{g} / \mathrm{mL}$, and $100 \mu \mathrm{g} / \mathrm{mL}$ (Fig. 3a). Both hBD-2 and A-hBD-2 exhibited the greatest anti-S. aureus activity in the absence of NaCl. At concentrations of $50 \mathrm{mM}, 70 \mathrm{mM}$, and $100 \mathrm{mM} \mathrm{NaCl}, \mathrm{A}-\mathrm{hBD}-2$ showed higher anti-S. aureus activity than did hBD-2. hBD-2 and A-hBD-2 exhibited similar anti-S. aureus activity in the presence of $150 \mathrm{mM} \mathrm{NaCl}$ (Fig. 3b).

\section{$A-h B D-2$ increased the proliferation and stimulated the migration keratinocytes}

The effects of hBD-2 and A-hBD-2 on the proliferation of HaCaT cells are illustrated in Fig. 4. Following the incubation of HaCaT cells with $20 \mu \mathrm{g} / \mathrm{mL}$ hBD-2, $20 \mu \mathrm{g} / \mathrm{mL}$ A-hBD-2, or vehicle (control), the hBD-2 and A-hBD-2 groups showed greater cell viability compared with the control group (Fig. 4a). Furthermore, a greater number of $\mathrm{HaCaT}$ cells reached the $S$ phase (Fig. 4d and 4e). Proteins related to proliferation (cyclin D1 and cyclin D3 in Fig. 4b and $5 c$, respectively) were increased in the hBD-2 and A-hBD-2 groups compared with the control group. In the cell migration assay, hBD-2 and A-hBD-2 groups also showed higher cell numbers compared with the control group. There was no significant difference between the hBD-2 and A-hBD-2 groups in terms of promoting HaCaT cell migration (Fig. 5). We further verified the effect of hBD-2 or A-hBD-2 on freshly isolated human keratinocytes. Our results suggested that both hBD-2 and A-hBD-2 have a positive effect on their proliferation and migration (Fig. 6).
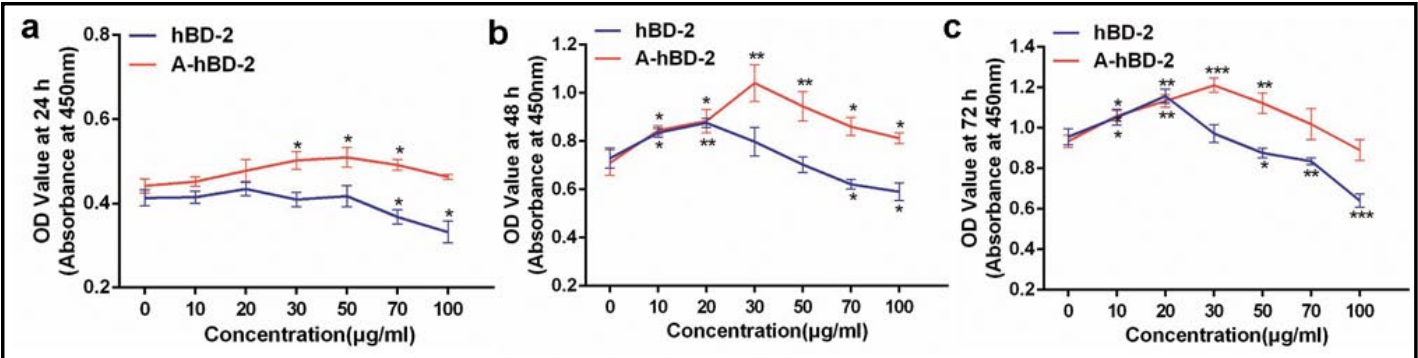

Fig. 2. High concentrations of A-hBD-2 had lower cytotoxic effects in HaCaT cells than hBD-2. (a-c) HaCaT cells were treated with hBD-2 or A-hBD-2 (0-100 $\mu \mathrm{g} / \mathrm{mL})$ for $24 \mathrm{~h}(\mathrm{a}), 48 \mathrm{~h}$ (b), and $72 \mathrm{~h}$ (c). CCK8 assay was then performed to evaluate cytotoxicity, which was reflected in cell numbers. All experiments were performed in triplicate. Statistical analysis was performed for various concentrations of peptides to $0 \mu \mathrm{g} /$ $\mathrm{mL}$ peptides. Data are expressed as the mean \pm SD. In the cell and animal experiments, $20 \mu \mathrm{g} / \mathrm{mL}$ hBD-2 and $20 \mu \mathrm{g} / \mathrm{mL}$ A-hBD-2 were used. ${ }^{*} \mathrm{P}<0.05,{ }^{* *} \mathrm{P}<0.01,{ }^{* * *} \mathrm{P}<0.001$. 


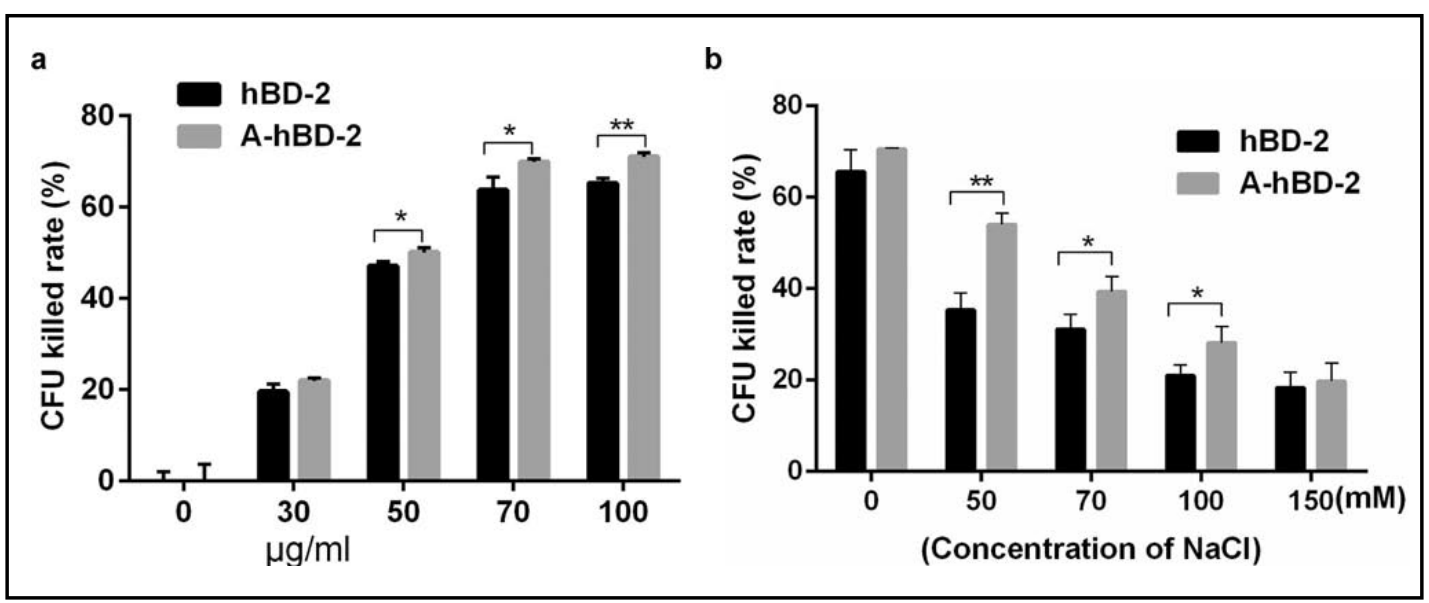

Fig. 3. A-hBD-2 exhibited higher antimicrobial activity and stronger structural stability compared with hBD-2. (a) Various concentrations of hBD-2 and A-hBD-2 (0-100 $\mu \mathrm{g} / \mathrm{mL})$ were incubated with S. aureus for $24 \mathrm{~h}$ and tested for antimicrobial activity using the CFU assay. (b) S. aureus was incubated with $20 \mu \mathrm{g} / \mathrm{mL}$ hBD-2 and $20 \mu \mathrm{g} / \mathrm{mL}$ A-hBD-2 at various concentrations of $\mathrm{NaCl}$ for $24 \mathrm{~h}$ and tested for structural stability using the CFU assay. All experiments were performed in triplicate. Data are expressed as the mean \pm SD. ${ }^{*} \mathrm{P}<0.05,{ }^{* *} \mathrm{P}<0.01$.

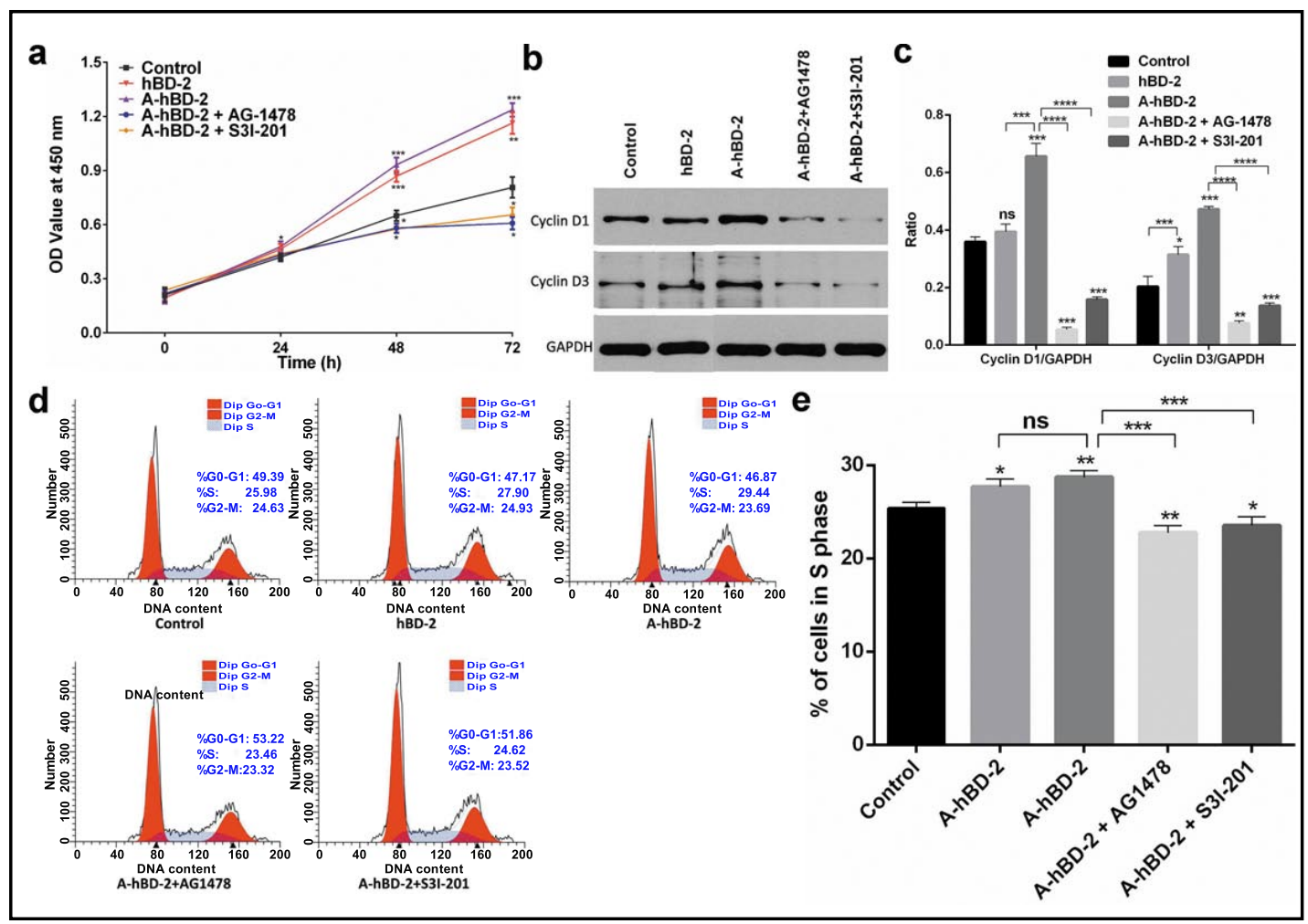

Fig. 4. A-hBD-2 treatment promoted HaCaT cell proliferation. (a) HaCaT cells were separately incubated with PBS, hBD-2, A-hBD-2, A-hBD-2 and AG1478, or A-hBD-2 and S3I-201 for 24 h, 48 h, or 72 h. Cell numbers were then detected by CCK8 assay. (b, c) HaCaT cells were separately incubated with PBS, hBD-2, A-hBD-2, A-hBD-2 and AG1478, or A-hBD-2 and S3I-201 for $48 \mathrm{~h}$, and the protein levels of cyclin D1 and cyclin D3 were detected by western blot. (e, d) HaCaT cells were separately incubated with vehicle, hBD-2, A-hBD-2, A-hBD-2 and AG1478, or A-hBD-2 and S3I-201 for $48 \mathrm{~h}$, and the cell cycles were detected by flow cytometry. All experiments were performed in triplicate. Data are expressed as the mean $\pm \mathrm{SD}$. ${ }^{*} \mathrm{P}<0.05$, ** $\mathrm{P}<0.01,{ }^{* * *} \mathrm{P}<0.001$. 


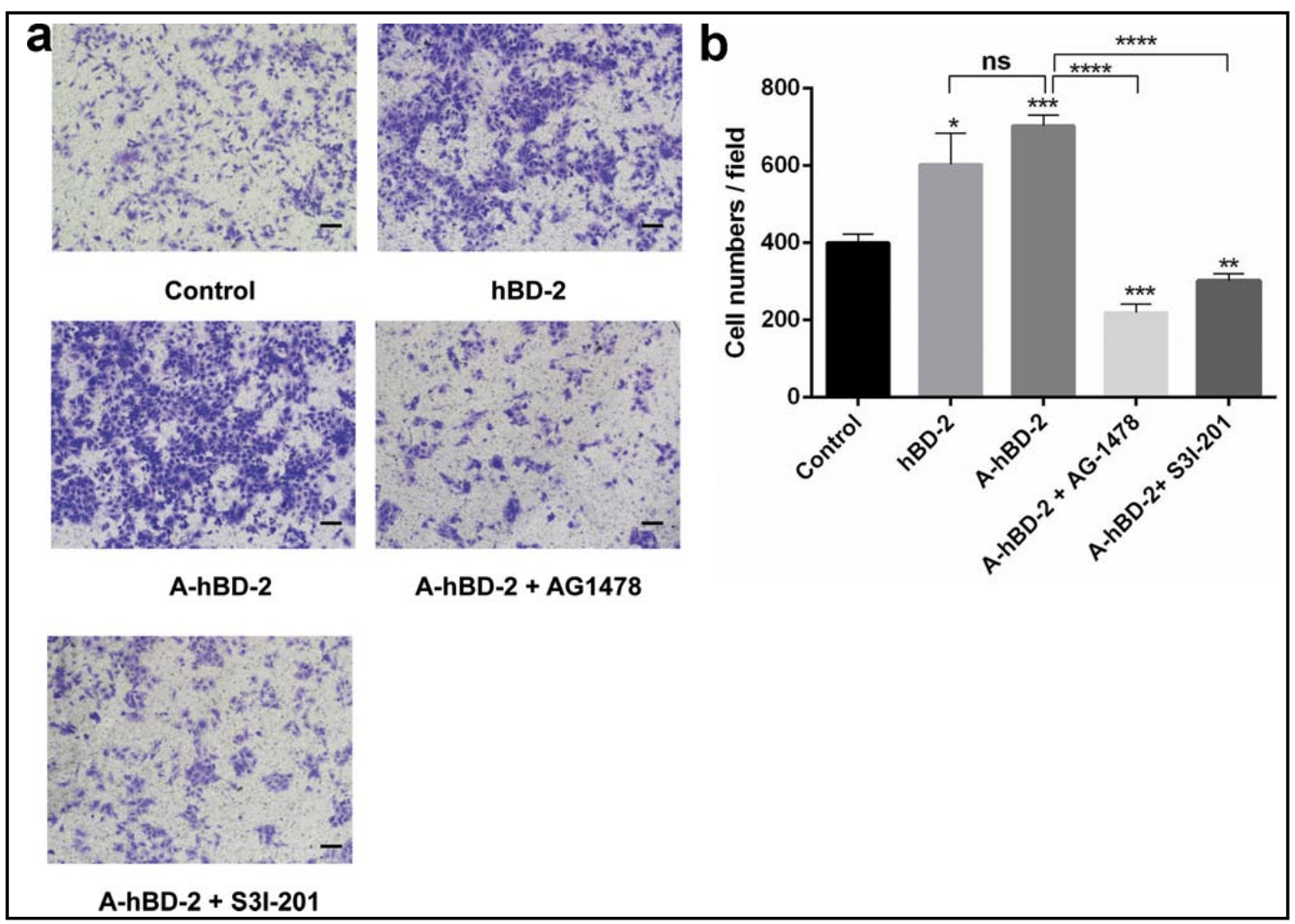

Fig. 5. A-hBD-2 treatment promoted HaCaT cell migration. The Matrigel transwell-assay was used to detect the migration of HaCaT cells. HaCaT cells were separately incubated with vehicle, hBD-2, A-hBD-2, A-hBD-2 and AG1478, or A-hBD-2 and S3I-201 for $48 \mathrm{~h}$ and the cells numbers were counted at $10 \times$ magnification. All experiments were performed in triplicate. Data are expressed as the mean $\pm \mathrm{SD} .{ }^{* * *} \mathrm{P}<0.001$.

Fig. 6. Effect of hBD2 and A-hBD-2 on the proliferation and migration of fresh human keratinocytes. Following incubation of the keratinocytes with vehicle, hBD2 , or A-hBD-2, the experimental groups showed higher cell viability compared with the control group. In the cell migration assay, the experimental groups showed a higher number of cells compared with the control group. (a)

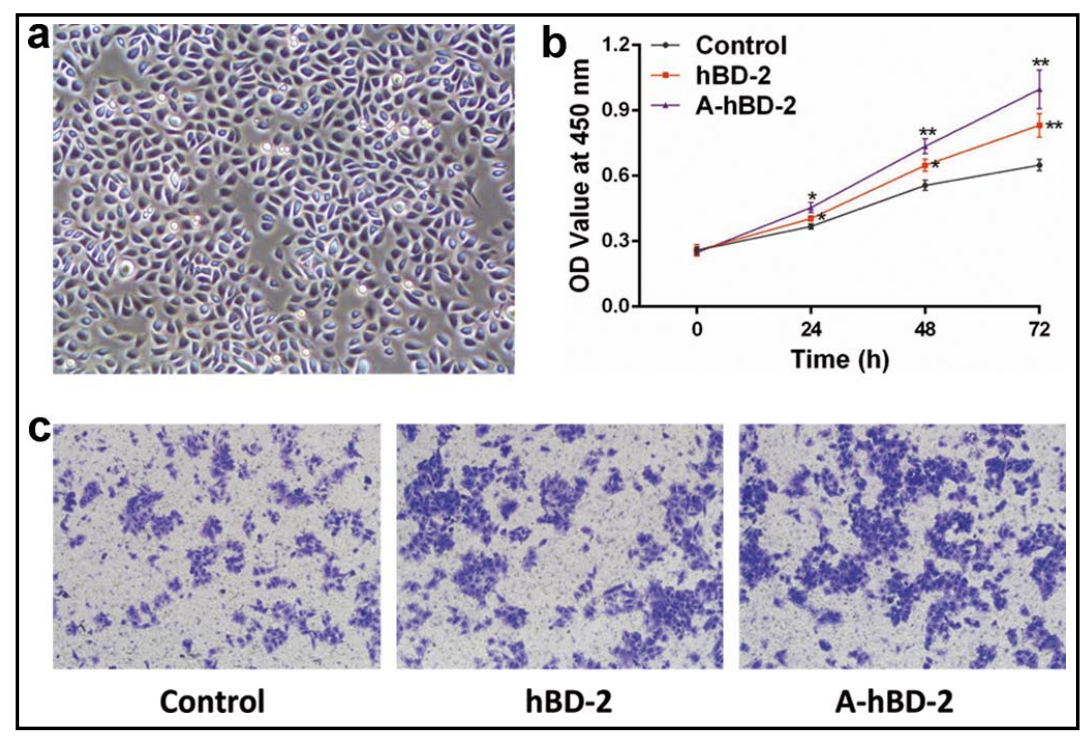
Morphology of human keratinocytes under an invert microscope (10x). (b) Effect of hBD-2 and A-hBD-2 on the proliferation of keratinocytes. (c) Effect of hBD-2 and A-hBD-2 on the migration of keratinocytes. All experiments were performed in triplicate. Data are expressed as the mean $\pm \mathrm{SD}$. ${ }^{*} \mathrm{P}<0.05,{ }^{*} \mathrm{P}<0.01$. 


\section{Cellular Physiology Cell Physiol Biochem 2018;51:647-663 and Biochemistry \begin{tabular}{l|l} 
DOI: $10.1159 / 000495320$ & (c) 2018 The Author(s). Published by S. Karger AG, Basel \\
www.karger.com/cpb
\end{tabular}

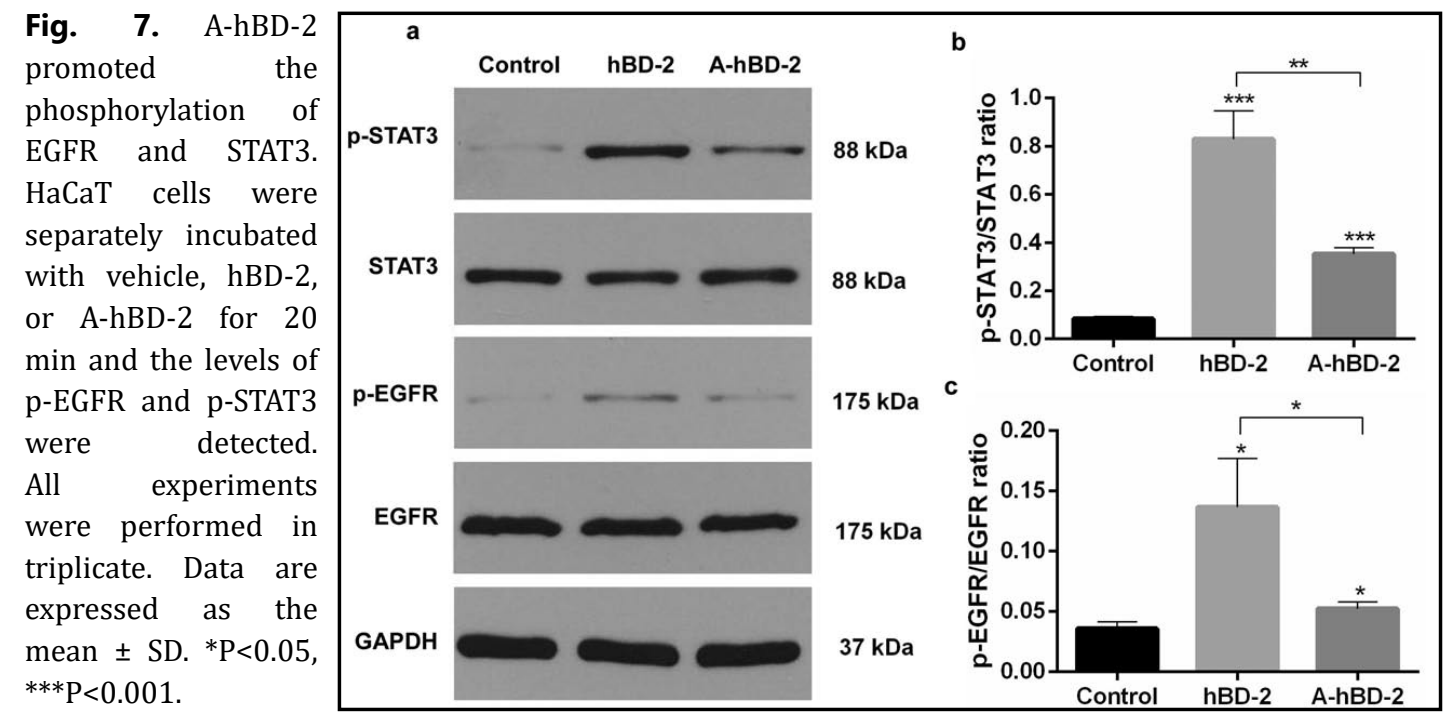

A-hBD-2 induced keratinocytes proliferation and migration by phosphorylation of EGFR and STAT3

Previous studies have reported that EGFR and STAT3 are phosphorylated by hBD-2 and involved in the processes of migration and proliferation in keratinocytes [14, 15]. In this study, we investigated whether A-hBD-2 induces the phosphorylation of EGFR and STAT3 in HaCaT cells. EGFR and STAT3 were phosphorylated 20 min after the addition of hBD$2(20 \mu \mathrm{g} / \mathrm{mL})$ or A-hBD-2 $(20 \mu \mathrm{g} / \mathrm{mL})$ in HaCaT cells (Fig. 7). The A-hBD-2 group showed a higher rate of EGFR and STAT3 phosphorylation compared with the control group. To further confirm our conclusion that the phosphorylation of EGFR and STAT3 is required for migration and proliferation of keratinocytes, $\mathrm{HaCaT}$ cells were pretreated with $50 \mathrm{nM}$ antiEGFR inhibitor (AG1478) or $50 \mu \mathrm{M}$ anti-STAT3 (S3I-201), and proliferation and migration assays were performed. AG1478 and S3I-201 were markedly reduced and A-hBD-2 mediated the proliferation and migration of keratinocytes (Fig. 4b-4e, 5a, and 5b). These observations implied that the activation of EGFR and STAT3 is necessary for A-hBD-2 mediated migration and proliferation of keratinocytes.

\section{$A-h B D-2$ induced keratinocyte proliferation via the inhibition of differentiation}

To investigate the effects of A-hBD-2 on keratinocyte proliferation and differentiation, the expression of KRT 5 and KRT 14 proteins, which are associated with keratinocyte proliferation, and KRT 1 and KRT 10, which are related to keratinocyte differentiation, were assessed. Our data indicated that the epidermal basal layer marker KRT 5 and KRT 14, but not the differentiation markers KRT 1 and KRT 10, were significantly increased following stimulation with hBD-2 or A-hBD-2 (Fig. 8a and 8b) compared with the control group (vehicle). To further demonstrate that hBD-2 or A-hBD-2 inhibits keratinocyte differentiation, we measured the levels of loricrin and filaggrin because they are increased in the terminal differentiation of keratinocytes. The expression levels of Ioricrin and filaggrin were suppressed after stimulation with hBD-2 or A-hBD-2 compared with the control group (Fig. 8c).

\section{$A-h B D-2$ elicited keratinocytes intracellular $\mathrm{Ca}^{2+}$ mobilization}

Previous studies have shown that AMPs, including hBD-2, induce rapid $\mathrm{Ca}^{2+}$ flux across the plasma membrane, elevating $\mathrm{Ca}^{2+}$ concentrations in keratinocytes. Such $\mathrm{Ca}^{2+}$ influx has been linked to the migration and proliferation of keratinocytes. Therefore, we examined the ability of A-hBD-2 to mobilize intracellular $\mathrm{Ca}^{2+}$ in keratinocytes. We observed that hBD-2 and A-hBD-2 markedly elevated the concentrations of intracellular $\mathrm{Ca}^{2+}$ in $\mathrm{HaCaT}$ cells (Fig. 9).

\section{KARGER}




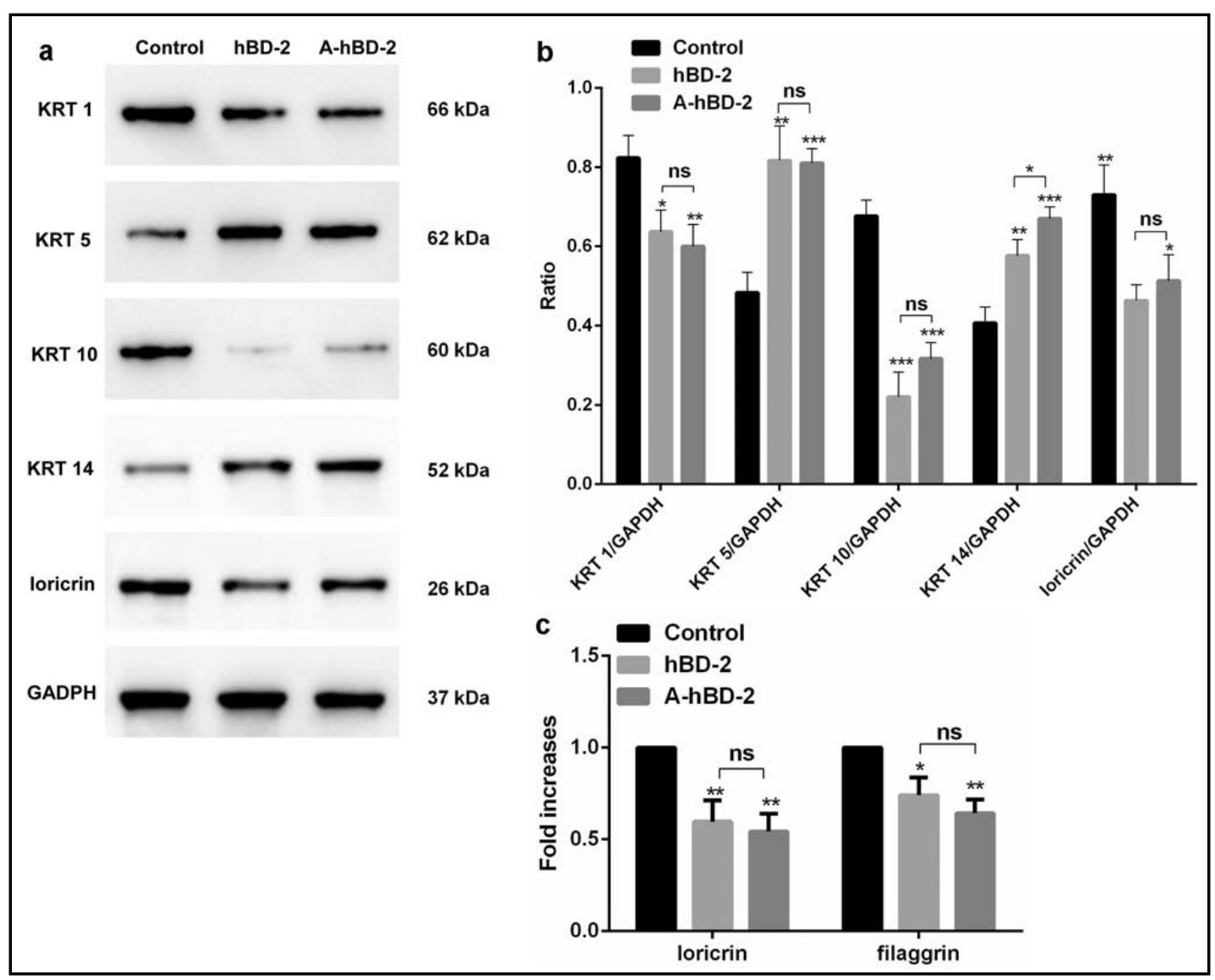

Fig. 8. A-hBD-2 induced HaCaT cell proliferation but suppressed differentiation. (a, b) Western blot patterns for KRT1, KRT5, KRT10, KRT14, and Ioricrin were detected after stimulation of HaCaT cells with hBD-2, A-hBD-2, or vehicle. (c) RT-PCR on Ioricrin and filaggrin were detected after stimulation of HaCaT cells with hBD-2, A-hBD-2, or vehicle. All experiments were performed in triplicate. Data are expressed as the mean \pm SD. ${ }^{*} \mathrm{P}<0.05,{ }^{* *} \mathrm{P}<0.01,{ }^{* * *} \mathrm{P}<0.001$.

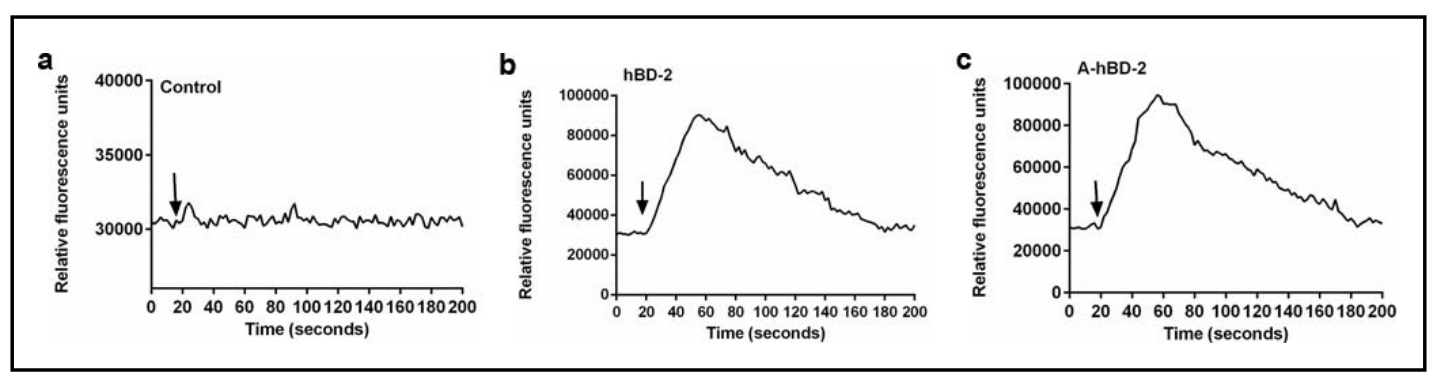

Fig. 9. A-hBD-2 increased HaCaT intracellular $\mathrm{Ca}^{2+}$ concentration. Fura-2-AM-loaded HaCaT cells were incubated with $20 \mu \mathrm{g} / \mathrm{mL}$ hBD-2, $20 \mu \mathrm{g} / \mathrm{mL}$ A-hBD-2, or medium containing $0.01 \%$ acetic acid at $37^{\circ} \mathrm{C}$. Data shown as fluorescence counts were representative of three independent experiments. Arrows indicate the addition of hBD-2, A-hBD-2, or acetic acid.

A-hBD-2 increased gene expression of pro-and anti-inflammatorycytokinesand chemokines and induced production of pro- and anti-inflammatory cytokines and chemokines

To further investigate the effects of A-hBD-2 in wound healing, we analyzed whether A-hBD-2 induced mRNA expression of various chemokines and pro- and anti-inflammatory cytokines from keratinocytes. HaCaT cells were incubated with $20 \mu \mathrm{g} / \mathrm{mL}$ hBD-2 or $20 \mu \mathrm{g} /$ 


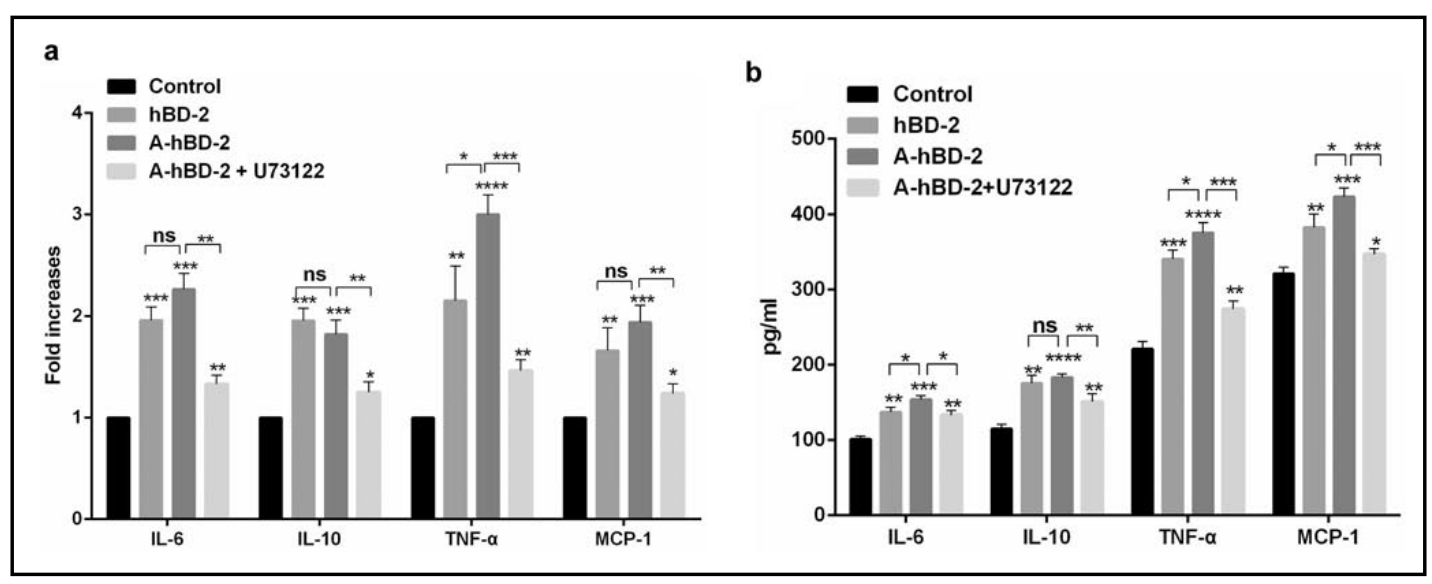

Fig. 10. A-hBD-2 treatment increased the secretion of pro- and anti-inflammatory cytokines and chemokines and the PLC signaling pathway involved in this process. (a) HaCaT cells were separately incubated with vehicle, hBD-2, A-hBD-2, or A-hBD-2 and U73122 for $6 \mathrm{~h}$, and the gene expression of proand anti-inflammatory cytokines and chemokines in HaCaT cells was detected using RT-PCR. (b) HaCaT cells were separately incubated with vehicle, hBD-2, A-hBD-2, or A-hBD-2 and U73122 for $48 \mathrm{~h}$, and the production of pro- and anti-inflammatory cytokines and chemokines in HaCaT cells was detected using ELISA. All experiments were performed in triplicate. Data are expressed as the mean $\pm \mathrm{SD} .{ }^{*} \mathrm{P}<0.05,{ }^{* *} \mathrm{P}<0.01$, $* * * \mathrm{P}<0.001, * * * * \mathrm{P}<0.0001$.

$\mathrm{mL}$ A-hBD-2 for $6 \mathrm{~h}$, and gene expression was analyzed using RT-PCR. It was found that hBD2 and A-hBD-2 significantly induced mRNA expression of IL-6, IL-10, TNF- $\alpha$, and MCP-1 (Fig. 10a). Since hBD-2 and A-hBD-2 increased the gene expression of chemokines and pro- and anti-inflammatory cytokines, we concluded that they stimulate keratinocytes to produce the corresponding proteins. Following the stimulation of keratinocytes with hBD-2 or A-hBD-2 for $48 \mathrm{~h}$, ELISA kits were used to detect the levels of chemokines and pro- and antiinflammatory cytokines in cell-free supernatants. As shown in Fig. 10b, hBD-2 and A-hBD-2 induced the production of IL-6, IL-10, TNF- $\alpha$, and MCP-1 from keratinocytes. Furthermore, A-hBD-2 induced greater levels of IL-6, TNF- $\alpha$, and MCP-1 production than did hBD-2.

\section{A-hBD-2-mediated keratinocytes production of chemokines and cytokines requires PLC} activation

Previous studies have found that the PCL-mediated signaling pathway is necessary for the function of hBD-2 on keratinocytes. Therefore, to investigate whether A-hBD-2 activates keratinocytes through the PLC-mediated signaling pathway, HaCaT cells were pretreated with $10 \mu \mathrm{M}$ U73122 for $2 \mathrm{~h}$ before stimulation with $20 \mu \mathrm{g} / \mathrm{mL}$ A-hBD-2. U73122 pretreatment decreased the stimulatory effects of A-hBD-2 on the production of IL-6, IL-10, TNF- $\alpha$, and MCP-1 (Fig. 10).

\section{$A-h B D-2$ promoted wound healing in vivo}

Following the application of PBS and hBD-2 or A-hBD-2 to the wound, we investigated the effects of each treatment on wound healing rate. At 3 days after surgery, there were no significant differences in the wound healing rates between the three groups. However, at 5 days after surgery, the hBD-2 and A-hBD-2 groups showed greater wound healing rates compared with the control group (Fig. 11a and 11b). In addition, epidermal thicknesses in the hBD-2 and A-hBD-2 group also increased compared to the control group (Fig. 11c and $11 d)$. These results indicated that A-hBD-2 played a positive role in promoting skin wound healing. 


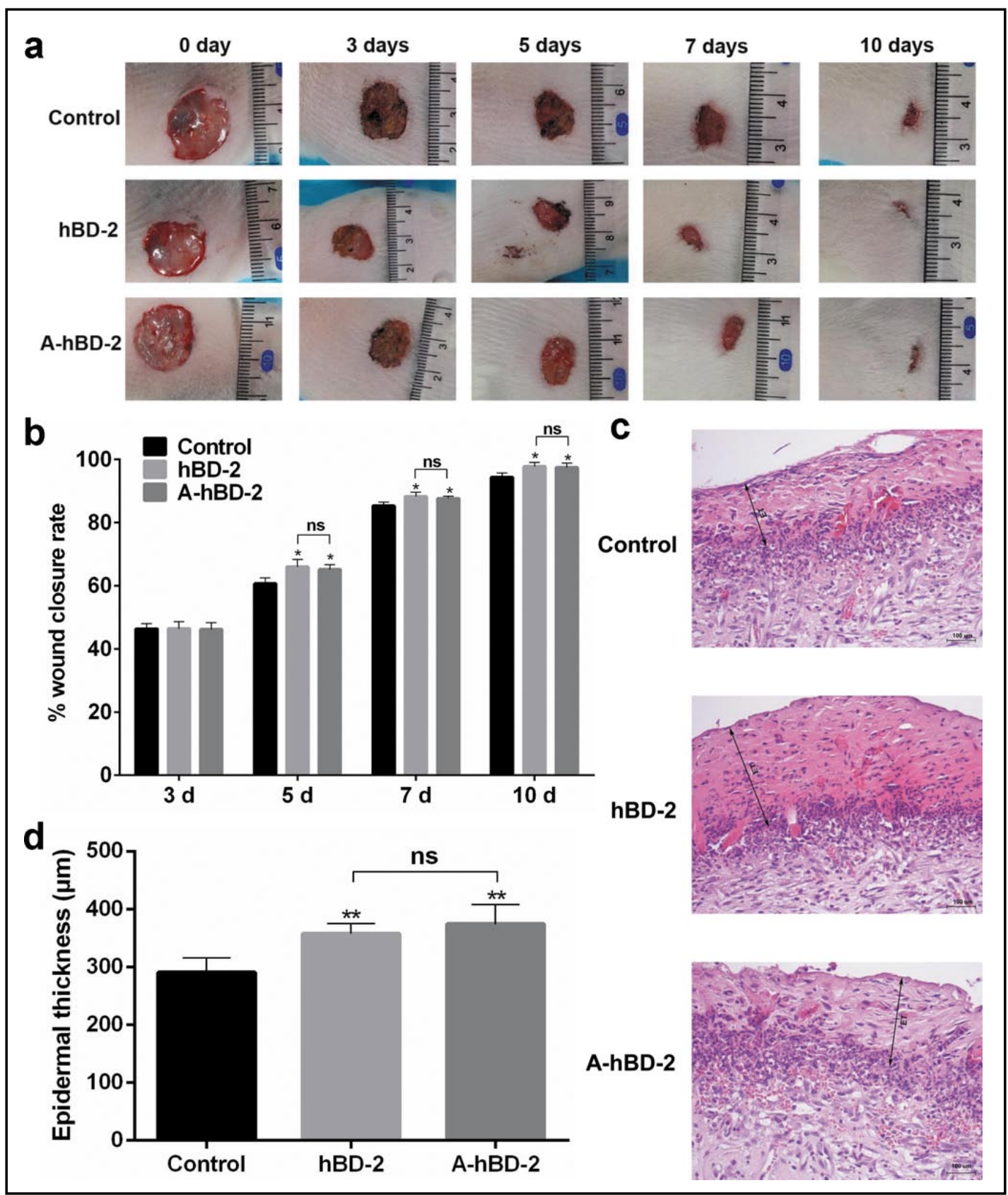

Fig. 11. A-hBD-2 treatment accelerated wound closure in Sprague-Dawley rats. (a) The macroscopic appearance of wound healing at days $0,3,5,7$, and 10 after surgery. Rats treated with $20 \mu \mathrm{g} / \mathrm{mL}$ hBD-2 or 20 $\mu \mathrm{g} / \mathrm{mL}$ A-hBD-2 showed smaller wound closure areas compared with the control group. (b) Digital images of wounds from the control group ( $n=5)$, hBD-2 group $(n=5)$, and A-hBD-2 group $(n=5)$ were analyzed for wound closure rates. (c, d) Digital images of H\&E stained wounds were captured using a Leica scope and software (200x). The epidermal thickness was analyzed. Values are shown as the mean $\pm \mathrm{SD}$. ${ }^{*} \mathrm{P}<0.05$, ${ }^{* *} \mathrm{P}<0.01$. 


\section{Cellular Physiology Cell Physiol Biochem 2018;51:647-663

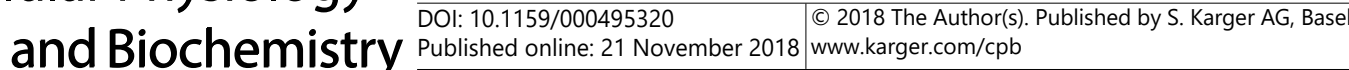 \\ Mi et al.: a-Hbd-2 Promotes Wound Healing via Keratinocyte Stimulation}

\section{Discussion}

In this study, we found that the replacement of GIGDP on the N-terminal of hBD-2 with APKAM, decreases the compound's cytotoxicity in HaCaT cells. Since AMPs have reduced resistance to salt sensitivity, they are potential options for future novel antibiotics, thus we tested whether the designed peptide A-hBD-2 had lower salt sensitivity and stronger structure ability. Our data indicated that A-hBD-2 has stronger anti-S. aureus activity under various concentrations $(50 \mu \mathrm{g} / \mathrm{mL}, 70 \mu \mathrm{g} / \mathrm{mL}$, and $100 \mu \mathrm{g} / \mathrm{mL}$ ) compared with hBD-2. Natural AMPs lose their antimicrobial activity at physiological salt concentrations, thereby limiting their potential clinical application [16]. Our study found that both hBD-2 and A-hBD-2 had lower antibacterial abilities with increased $\mathrm{NaCl}$ concentrations. However, A-hBD-2 had lower salt sensitivity than hBD-2 under higher concentrations of $\mathrm{NaCl}(50 \mathrm{mM}, 70 \mathrm{mM}$, and $100 \mathrm{mM}$ ). These results suggested that A-hBD-2 is more effective for wound healing at the same peptide concentration under the same wound conditions. It is worth noting that the $\mathrm{N}$-terminal peptide was modified and an $\alpha$-helix structure added, and this may have been important in improving the stability of peptides [17]. Changing the amino acid sequence on the N- and C-terminals of LL-37 decreased its cytotoxicity and enhance its structural stability and antibacterial activity [18]. These modifications augmented the antibacterial activity of peptides, suggesting a template for future peptide synthesis.

When the skin is injured, keratinocytes at the wound edge receive signals to suppress differentiation and promote proliferation and migration in order to enable reepithelialization $[19,20]$. During the proliferative phase of wound healing, it is important to promote keratinocyte migration to the wound site; thus, proliferation ability is essential. To achieve this, an ideal drug would promote the migration and proliferation of keratinocytes. Given that previous studies have reported that hBD-2 promotes the migration and proliferation of keratinocytes [8], we hypothesized that the designer peptide A-hBD-2 would have the same abilities. Our results indicated that A-hBD-2 elicits positive effects on keratinocyte proliferation. In addition to promoting keratinocyte proliferation, hBD-2 also stimulates keratinocyte migration. In the current study, hBD-2 and A-hBD-2 exhibited a stimulatory role in keratinocyte migration in vitro. These results showing that hBD-2 and A-hBD-2 promote keratinocyte proliferation and migration were further supported by our in vivo study because wound closure rate and epidermal thicknesses were increased in the two experimental groups versus the control group. Since HaCaT cells are immortalized, this may impact the proliferation and migration rates that were increased by hBD-2 or A-hBD-2.

The EGFR signaling pathway is important for the growth and survival of epidermal cells. Its activation stimulates cell migration and proliferation in wounds and thus promotes healing [21]. When EGFR protein expression is suppressed, the level of p-STAT3 protein also decreases [22]. Previous studies have shown that the EGFR signaling pathway is involved in hBD-2-induced proliferation and migration of keratinocytes [8]. As A-hBD-2 has a similar structure to hBD-2, we investigated whether the effect of A-hBD-2 on the proliferation and migration of keratinocyte is also similar to hBD-2. A-hBD-2 activated the phosphorylation of EGFR and STAT3 while blocking EGFR or STAT3 significantly inhibited the migration and proliferation of keratinocytes. The mechanism of EGFR activation by A-hBD-2 remains unclear and requires further investigation. Previous studies have reported that EGFR activation could also induce hBDs production from keratinocytes [23]. Thus, it could be suggested that the close interaction between hBDs and EGFR has multiple benefits for wound healing. In the present study, we noticed that the effects of A-hBD-2 on the proliferation and migration of keratinocytes were stronger than those of hBD-2. However, the effects of A-hBD-2 were weaker than the effects of hBD-2 on the phosphorylation of EGFR and STAT3. In our opinion, there are several reasons underlying these results. First, $30 \mu \mathrm{g} / \mathrm{mL}$ A-hBD-2 or $20 \mu \mathrm{g} / \mathrm{mL}$ hBD-2 was the best concentration for keratinocytes. To avoid the effect of dose variation, we used $20 \mu \mathrm{g} / \mathrm{mL}$ in both experimental groups. Second, we detected the effects of A-hBD-2 and hBD- 2 on the phosphorylation of EGFR and STAT3 after 20 min. Third, the underlying mechanisms of the proliferation and migration of keratinocytes are complicated and there 


\section{Cellular Physiology Cell Physiol Biochem 2018;51:647-663 \begin{tabular}{ll|l} 
and Biochemistry & $\begin{array}{l}\text { DOl: 10.1159/000495320 } \\
\text { Published online: } 21 \text { November } 2018\end{array}$ & $\begin{array}{l}\text { (2018 The Author(s). Published by S. Karger AG, Basel } \\
\text { www.karger.com/cpb }\end{array}$ \\
\cline { 2 - 3 }
\end{tabular} \\ Mi et al.: a-Hbd-2 Promotes Wound Healing via Keratinocyte Stimulation}

are several signaling pathways involved in these processes $[24,25]$. It seems that A-hBD-2 promotes the proliferation and migration of keratinocytes through other pathways, such as AKT and ERK signaling pathways, and thus needs to be further investigated.

The process of re-establishing the barrier function of the skin following injury requires the proliferation of keratinocytes in the basal layer and their differentiation in the upper layers of the epidermis [26]. During the remodeling phase of wound healing, keratinocyte proliferation is followed by differentiation, which is established by a switch from KRT5/ KRT14 in the basal layer to KRT1/KRT10 in suprabasal layers [27, 28]. Higher levels of KRT5/ KRT14 reflect stronger keratinocyte proliferation activity. Our results suggesting that hBD2 or A-hBD-2 promoted the proliferation of keratinocytes is reflected by increased levels of KRT5/14. During the terminal differentiation of keratinocytes, the levels of loricrin and filaggrin are increased [29]. Previous reports have stated that the $S$. aureus surface adhesin clumping factor B could have a high-affinity interaction with the cornified envelope protein loricrin, enabling the attachment of bacteria to the anterior nares epithelium [30]. Our data indicated that A-hBD-2 may exhibit its antibacterial effect by reducing the level of loricrin during wound healing. Deficiency in reepithelization is one of the causes of a lack of barrier formation in chronic wounds and diabetic foot ulcers [31]. This may be due to incomplete differentiation of keratinocytes, represented by suppressed differentiation markers such as KRT1/KRT10, filaggrin, and loricrin [32]. As differentiation of keratinocytes is important in the formation of an adequate skin barrier, A-hBD-2 is not recommended for the remodeling stage of wound healing.

A key signaling molecule during epidermal wound repair is $\mathrm{Ca}^{2+}[33]$. Recent studies have reported that appropriate drugs, activator protein-1, or exogenous mechanical forces on keratinocytes can accelerate wound healing [34-36]. Niyonsaba also reported that hBD-2 increases the concentration of intracellular $\mathrm{Ca}^{2+}[8]$. In this study, we found that A-hBD-2 had similar effects on promoting the influx of extracellular $\mathrm{Ca}^{2+}$. Previous studies have reported that the transient influx of extracellular $\mathrm{Ca}^{2+}$ occurs through TRPC6 or $\mathrm{IP}_{3} \mathrm{R}$ channels [37, 38]. The TRPC6 activator hyperforin has also been reported to accelerate wound healing through the ATP-Ca ${ }^{2+}$ signaling pathway in keratinocytes [39]. In future experiments, we aim to discover the channels and signaling pathways that are involved in the A-hBD-2-induced proliferation and migration of keratinocytes.

In the current study, we observed that both gene and protein expression of pro- and anti-inflammatory cytokines and chemokines such as IL-6, IL-10, TNF- $\alpha$, and MCP-1 was stimulated by hBD-2 and A-hBD-2 in keratinocytes. Prior studies have reported that, following stimulation by external stresses (such as inflammation, wounding, or oxidative stress), epithelial cells produce multiple AMPs to enhance innate immunity $[8,40]$. By adding AMPs directly to the epithelial cells, different cytokines and chemokines produced by keratinocytes modulate the innate immune response. Therefore, the ability of A-hBD-2 to induce proinflammatory cytokine and chemokine production from keratinocytes suggests that A-hBD-2 has immunomodulatory effects on wound healing. In addition, our results indicated that A-hBD-2 enhances the level of the anti-inflammatory cytokine IL-10, which plays a key role in the process of wound healing from the inflammatory phase to the proliferative phase [41]. PLC is a key signaling protein that plays a significant role in multiple physiological processes in cells. Previous studies have reported that AMPs can stimulate the release of cytokines via the activation of PLC signaling and have immunomodulatory effects $[5,42]$. The PLC-dependent pathway is involved in the A-hBD-2-induced production of cytokines and chemokines, as demonstrated by the inhibitory effects of U73122 against A-hBD- 2 and confirmed by the decreased production of cytokines and chemokines.

\section{Conclusion}

In summary, our findings support our previous hypothesis that the designer antimicrobial peptide A-hBD-2 has lower cytotoxicity, stronger structural stability, and 


\section{Cellular Physiology Cell Physiol Biochem 2018;51:647-663 and Biochemistry Publisher $\begin{aligned} & \text { DOI: } 10.1159 / 000495320 \\ & \text { (c) } 2018 \text { The Author(s). Published by S. Karger AG, Basel } \\ & \text { www.karger.com/cpb }\end{aligned}$ \\ Mi et al.: a-Hbd-2 Promotes Wound Healing via Keratinocyte Stimulation}

higher antimicrobial activity compared to hBD-2. In addition, A-hBD-2 functions in wound healing by stimulating the migration and proliferation of keratinocytes and modulating the immune response. These multiple functions of A-hBD- 2 imply that it has potential as a novel drug for wound healing.

\section{Acknowledgements}

This work was supported by the National Science Foundation of China (No.81772345), Science and Technology Department of Hubei Province (No.2016CFB424), Development Center for Medical Science and Technology National Health and Family Planning Commission of the People's Republic of China (ZX-01-C2016024). Bobin Mi and Guohui Liu conceived and designed the experiments. Jing Liu, $\mathrm{Wu}$ Zhou, Yi Liu and Liangcong Hu performed the experiments. Bobin Mi and Jing Liu wrote the manuscript and made the same contribution to the manuscript. Yukun Liu provided and cultured the freshly human keratinocytes. Adriana C. Panayi revised the language and figures of the manuscript. The final manuscript has been read and approved by all authors.

\section{Disclosure Statement}

The authors declare that they have no conflicts of interest.

\section{References}

1 Fjell CD, Hiss JA, Hancock RE, Schneider G: Designing antimicrobial peptides: form follows function. Nature reviews Drug discovery 2011;11:37-51.

2 Mohanty T, Alberius P, Schmidtchen A, Reiss K, Schroder JM, Sorensen OE: Saliva induces expression of antimicrobial peptides and promotes intracellular killing of bacteria in keratinocytes by epidermal growth factor receptor transactivation. The British journal of dermatology 2017;176:403-412.

3 Baroni A, Donnarumma G, Paoletti I, Longanesi-Cattani I, Bifulco K, Tufano MA, Carriero MV: Antimicrobial human beta-defensin-2 stimulates migration, proliferation and tube formation of human umbilical vein endothelial cells. Peptides 2009;30:267-272.

4 Griffith GL, Kasus-Jacobi A, Pereira HA: Bioactive Antimicrobial Peptides as Therapeutics for Corneal Wounds and Infections. Advances in wound care 2017;6:175-190.

5 Niyonsaba F, Nagaoka I, Ogawa H, Okumura K: Multifunctional antimicrobial proteins and peptides: natural activators of immune systems. Current pharmaceutical design 2009;15:2393-2413.

6 Schauber J, Gallo RL: Expanding the roles of antimicrobial peptides in skin: alarming and arming keratinocytes. The Journal of investigative dermatology 2007;127:510-512.

7 Sheng Q, Lv Z, Cai W, Song H, Qian L, Mu H, Shi J, Wang X: Human beta-defensin-3 promotes intestinal epithelial cell migration and reduces the development of necrotizing enterocolitis in a neonatal rat model. Pediatric research 2014;76:269-279.

-8 Niyonsaba F, Ushio H, Nakano N, Ng W, Sayama K, Hashimoto K, Nagaoka I, Okumura K, Ogawa H: Antimicrobial peptides human beta-defensins stimulate epidermal keratinocyte migration, proliferation and production of proinflammatory cytokines and chemokines. The Journal of investigative dermatology 2007;127:594-604.

-9 Leelakanok N, Fischer CL, Bates AM, Guthmiller JM, Johnson GK, Salem AK, Brogden KA, Brogden NK: Cytotoxicity of HBD3 for dendritic cells, normal human epidermal keratinocytes, hTERT keratinocytes, and primary oral gingival epithelial keratinocytes in cell culture conditions. Toxicology letters 2015;239:90-96.

10 Jiang Z, Vasil AI, Hale JD, Hancock RE, Vasil ML, Hodges RS: Effects of net charge and the number of positively charged residues on the biological activity of amphipathic alpha-helical cationic antimicrobial peptides. Biopolymers 2008;90:369-383. 


\section{Cellular Physiology Cell Physiol Biochem 2018;51:647-663 \begin{tabular}{ll|l} 
and Biochemistry Published onlIne: 21 November 2018 & $\begin{array}{l}\text { (c) } 2018 \text { The Author(s). Published by S. Karger AG, Basel } \\
\text { www.karger.com/cpb }\end{array}$ \\
\hline
\end{tabular}}

Mi et al.: a-Hbd-2 Promotes Wound Healing via Keratinocyte Stimulation

11 Ozgur B, Sayar M: Role of Hydrophobic/Aromatic Residues on the Stability of Double-Wall beta-Sheet Structures Formed by a Triblock Peptide. The journal of physical chemistry B 2017;121:4115-4128.

12 Zhang SK, Song JW, Gong F, Li SB, Chang HY, Xie HM, Gao HW, Tan YX, Ji SP: Design of an alpha-helical antimicrobial peptide with improved cell-selective and potent anti-biofilm activity. Scientific reports 2016;6:27394.

13 Huang Y, He L, Li G, Zhai N, Jiang H, Chen Y: Role of helicity of alpha-helical antimicrobial peptides to improve specificity. Protein \& cell 2014;5:631-642.

14 Merkulova Y, Shen Y, Parkinson LG, Raithatha SA, Zhao H, Westendorf K, Sharma M, Bleackley RC, Granville DJ: Granzyme B inhibits keratinocyte migration by disrupting epidermal growth factor receptor (EGFR)mediated signaling. Biological chemistry 2016;397:883-895.

15 Yoo YH, Kim YR, Kim MS, Lee KJ, Park KH, Hahn JH: YAC tripeptide of epidermal growth factor promotes the proliferation of HaCaT keratinocytes through activation of EGFR. BMB reports 2014;47:581-586.

16 Chu HL, Yu HY, Yip BS, Chih YH, Liang CW, Cheng HT, Cheng JW: Boosting salt resistance of short antimicrobial peptides. Antimicrobial agents and chemotherapy 2013;57:4050-4052.

17 Castro MS, Cilli EM, Fontes W: Combinatorial synthesis and directed evolution applied to the production of alpha-helix forming antimicrobial peptides analogues. Current protein \& peptide science 2006;7:473-478.

18 Kim DJ, Lee YW, Park MK, Shin JR, Lim KJ, Cho JH, Kim SC: Efficacy of the designer antimicrobial peptide SHAP1 in wound healing and wound infection. Amino acids 2014;46:2333-2343.

19 Besson JCF, Hernandes L, Campos JM, Morikawa KA, Bersani-Amado CA, Matioli G: Insulin complexed with cyclodextrins stimulates epithelialization and neovascularization of skin wound healing in rats. Injury 2017;48:2417-2425.

20 Shatirishvili M, Burk AS, Franz CM, Pace G, Kastilan T, Breuhahn K, Hinterseer E, Dierich A, Bakiri L, Wagner EF, Ponta H, Hartmann TN, Tanaka M, Orian-Rousseau V: Epidermal-specific deletion of CD44 reveals a function in keratinocytes in response to mechanical stress. Cell death \& disease 2016;7:e2461.

-21 Nardini JT, Chapnick DA, Liu X, Bortz DM: Modeling keratinocyte wound healing dynamics: Cell-cell adhesion promotes sustained collective migration. Journal of theoretical biology 2016;400:103-117.

-22 Li B, Ding CM, Li YX, Peng JC, Geng N, Qin WW: Over-regulation of microRNA-133b inhibits cell proliferation of cisplatin-induced non-small cell lung cancer cells through PI3K/Akt and JAK2/STAT3 signaling pathway by targeting EGFR. Oncology reports 2018;39:1227-1234.

-23 Bayer A, Lammel J, Tohidnezhad M, Lippross S, Behrendt P, Kluter T, Pufe T, Cremer J, Jahr H, Rademacher F, Glaser R, Harder J: The Antimicrobial Peptide Human Beta-Defensin-3 Is Induced by Platelet-Released Growth Factors in Primary Keratinocytes. Mediators of inflammation 2017;2017:6157491.

24 Kenny FN, Drymoussi Z, Delaine-Smith R, Kao AP, Laly AC, Knight MM, Philpott MP, Connelly JT: Tissue stiffening promotes keratinocyte proliferation through activation of epidermal growth factor signaling. Journal of cell science 2018;131.

25 Shibata S, Tada Y, Asano Y, Hau CS, Kato T, Saeki H, Yamauchi T, Kubota N, Kadowaki T, Sato S: Adiponectin regulates cutaneous wound healing by promoting keratinocyte proliferation and migration via the ERK signaling pathway. Journal of immunology 2012;189:3231-3241.

-26 Yang B, Suwanpradid J, Sanchez-Lagunes R, Choi HW, Hoang P, Wang D, Abraham SN, MacLeod AS: IL-27 Facilitates Skin Wound Healing through Induction of Epidermal Proliferation and Host Defense. The Journal of investigative dermatology 2017;137:1166-1675.

-27 Wikramanayake TC, Stojadinovic 0, Tomic-Canic M: Epidermal Differentiation in Barrier Maintenance and Wound Healing. Advances in wound care 2014;3:272-280.

28 Zhang C, Xu Q Tan X, Meng L, Wei G, Liu Y, Zhang C: Astilbin decreases proliferation and improves differentiation in HaCaT keratinocytes. Biomedicine \& pharmacotherapy = Biomedecine \& pharmacotherapie 2017;93:713-720.

29 Lei H, Wang Y, Zhang T, Chang L, Wu Y, Lai Y: TLR3 activation induces S100A7 to regulate keratinocyte differentiation after skin injury. Science China Life sciences 2017;60:158-167.

30 Mulcahy ME, Geoghegan JA, Monk IR, O’Keeffe KM, Walsh EJ, Foster TJ, McLoughlin RM: Nasal colonisation by Staphylococcus aureus depends upon clumping factor B binding to the squamous epithelial cell envelope protein loricrin. PLoS pathogens 2012;8:e1003092.

-31 Usui ML, Mansbridge JN, Carter WG, Fujita M, Olerud JE: Keratinocyte migration, proliferation, and differentiation in chronic ulcers from patients with diabetes and normal wounds. The journal of histochemistry and cytochemistry : official journal of the Histochemistry Society 2008;56:687-696. 


\section{Cellular Physiology Cell Physiol Biochem 2018;51:647-663

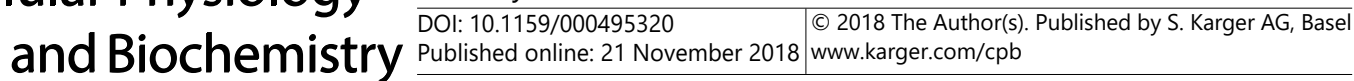 \\ Mi et al.: a-Hbd-2 Promotes Wound Healing via Keratinocyte Stimulation}

-32 Stojadinovic O, Pastar I, Vukelic S, Mahoney MG, Brennan D, Krzyzanowska A, Golinko M, Brem H, TomicCanic M: Deregulation of keratinocyte differentiation and activation: a hallmark of venous ulcers. Journal of cellular and molecular medicine 2008;12:2675-2690.

-33 Lansdown AB: Calcium: a potential central regulator in wound healing in the skin. Wound repair and regeneration : official publication of the Wound Healing Society [and] the European Tissue Repair Society 2002;10:271-285.

-34 Agha R, Ogawa R, Pietramaggiori G, Orgill DP: A review of the role of mechanical forces in cutaneous wound healing. The Journal of surgical research 2011;171:700-708.

35 Park KH, Kim KN, Park DR, Jang KY, Kim UH: Role of Nicotinic Acid Adenine Dinucleotide Phosphate (NAADP) in Keratinocyte Differentiation. The Journal of investigative dermatology 2015;135:1692-1694.

36 Yates S, Rayner TE: Transcription factor activation in response to cutaneous injury: role of AP-1 in reepithelialization. Wound repair and regeneration : official publication of the Wound Healing Society [and] the European Tissue Repair Society 2002;10:5-15.

-37 Chen X, Kintner DB, Luo J, Baba A, Matsuda T, Sun D: Endoplasmic reticulum Ca2+ dysregulation and endoplasmic reticulum stress following in vitro neuronal ischemia: role of $\mathrm{Na}+\mathrm{K}+-\mathrm{Cl}$ - cotransporter. Journal of neurochemistry 2008;106:1563-1576.

-38 Takada H, Furuya K, Sokabe M: Mechanosensitive ATP release from hemichannels and $\mathrm{Ca}(2)(+)$ influx through TRPC6 accelerate wound closure in keratinocytes. Journal of cell science 2014;127:4159-4171.

-39 Takada H, Yonekawa J, Matsumoto M, Furuya K, Sokabe M: Hyperforin/HP-beta-Cyclodextrin Enhances Mechanosensitive $\mathrm{Ca}(2+)$ Signaling in HaCaT Keratinocytes and in Atopic Skin Ex Vivo Which Accelerates Wound Healing. BioMed research international 2017;2017:8701801.

40 Wanke I, Steffen H, Christ C, Krismer B, Gotz F, Peschel A, Schaller M, Schittek B: Skin commensals amplify the innate immune response to pathogens by activation of distinct signaling pathways. The Journal of investigative dermatology 2011;131:382-390.

-41 Eming SA, Werner S, Bugnon P, Wickenhauser C, Siewe L, Utermohlen O, Davidson JM, Krieg T, Roers A: Accelerated wound closure in mice deficient for interleukin-10 The American journal of pathology 2007;170:188-202.

42 Phan TK, Lay FT, Hulett MD: Importance of phosphoinositide binding by human beta-defensin 3 for Aktdependent cytokine induction. Immunology and cell biology 2018;96:54-67. 